\title{
Os aniversários da abolição da escravatura e a imprensa ilustrada do Rio de Janeiro (1890-1902)
}

\author{
Aristeu Elisandro Machado Lopes* \\ Universidade Federal de Pelotas, Pelotas-RS, Brasil
}

\section{RESUMO}

A imprensa ilustrada do Rio de Janeiro celebrou em suas páginas os aniversários da Lei Áurea, que libertou os escravos em 1888. As celebraçôes da data ocorreram, sobretudo, nos anos 1890 , os primeiros do novo regime político advindo com a proclamação da república. Analisar como os aniversários de um evento político e social importante da história do Império do Brasil foram abordados no período republicano é o objetivo do artigo. Para esta análise serão averiguados dois periódicos - Revista Illustrada e Don Quixote - que trataram dos aniversários da aboliçấo com opinióes distintas e que possibilitam compreender o cenário político do começo do Brasil Republicano.

Palavras-chave: abolição; república; imprensa ilustrada; Rio de Janeiro; Angelo Agostini.

\section{ABSTRACT}

Rio de Janeiro's illustrated press celebrated the anniversaries of the Lei Áurea (the Golden Law), which freed slaves in Brazil in 1888. These celebrations occurred mostly in the 1890s, the first years of a new political regime that emerged with the proclamation of the Republic. The purpose of this article is to analyze how the Republican period approached the anniversaries of an important political and social event in the history of Brazil's Empire. We will be dealing with two magazines - Revista Illustrada and Don Quixote - that portrayed the Abolition through different points of view, thus enabling us to understand the political scenario in early Republican Brazil.

Keywords: abolition; republic; illustrated press; Rio de Janeiro; Angelo Agostini.

DOI - http://dx.doi.org/10.1590/2237-101X017033010

* Professor na Universidade Federal de Pelotas. E-mail: aristeuufpel@yahoo.com.br. 


\section{Considerações iniciais}

A imprensa ilustrada que circulou no Rio de Janeiro alcançou notoriedade, sobretudo, a partir da década de 1870 . Os periódicos se notabilizaram pela irreverência de suas ilustraçôes ao tratarem de assuntos variados e também aproveitaram os desenhos para criticar as mazelas sociais e defender seus pontos de vista. A campanha pelo fim da escravidão foi com constância abordada em suas páginas, fosse nas ilustraçóes, fosse nos artigos de opiniáo.

A Revista Illustrada, surgida em 1876 com os desenhos de seu fundador, Angelo Agostini, é o melhor exemplo. Marcelo Balaban ressalta, ao analisar as "imagens de negros" da Revis$t a$, que elas "oferecem um amplo conjunto de questóes ligadas à noções de raça e concepçôes de escravidão e do escravo, sobre como essas noçôes foram mobilizadas por alguns abolicionistas, além de tratar de uma série de temas e problemas sociais e políticos que cercam aquele campo tấo controverso e delicado". ${ }^{1}$ Ao longo dos anos que circulou, o periódico defendeu a abolição da escravatura e festejou sua conquista em 1888. Agostini, contudo, logo após a Lei Áurea, deixava o periódico e seguia em viagem para a Europa, de onde retornaria anos depois quando o Brasil já era uma república. Em seu retorno, o caricaturista que por anos esteve na confecção das ilustraçóes da Revista Illustrada não reassumiu o periódico e lançou, em 1895, Don Quixote, defendendo uma posição diferente daquela que circulava no seu antigo periódico.

Analisar os aniversários da lei que aboliu a escravidáo no Brasil nas páginas desses dois periódicos também é compreender o clima político dos primeiros anos da república brasileira. Como será abordado adiante, a Revista — que ao longo dos primeiros anos de circulação adotou uma posição simpática à causa republicana — após a abolição passou a criticar de maneira mais enfática os republicanos. Essa opinião somente seria revertida com a proclamação da república em 1889. A partir daquela data o periódico se tornaria um defensor republicano. Gilberto Oliveira destaca que no momento posterior à proclamação da república a Revista em "sucessivas ediçôes exibe textos e desenhos que beiram a adulação aberta".

E é justamente nessa defesa que é possível averiguar um dos prováveis motivos que levaram Agostini, depois de seu retorno, a fundar um novo periódico. ${ }^{3}$ Dessa forma, compreen-

\footnotetext{
BALABAN, Marcelo. A flor da nossa gente: análise de imagens de negros da Revista Illustrada. In: V Encontro Escravidão e Liberdade no Brasil Meridional. 2005, Porto Alegre. Anais... Porto Alegre: UFRGS, p. 2 (Anais eletrônicos).

${ }^{2}$ OLIVEIRA, Gilberto. Angelo Agostini ou impressöes de uma viagem da Corte à Capital Federal (1864-1910). Tese (Doutorado em História Social) — Programa de Pós-Graduação em História Social, Universidade de São Paulo, São Paulo, 2006, p. 197.

${ }^{3}$ Além da perda do caráter irreverente do jornal, outra possível explicação para a saída de Agostini da Revista Illustrada foi um conflito com a parte administrativa do periódico. Conforme Marcus Ribeiro, Agostini e Luiz de Andrade, sócio e redator da Revista, se encontraram após o seu retorno e resolveram continuar com a publicação do periódico com a colaboração dele, o que não aconteceu. Essa informação foi dada pela neta de Agostini, Mariana Alvim, entrevistada por Marcus Ribeiro. RIBEIRO, Marcus Tadeu Daniel. Revista
} 
der os processos políticos nos quais os periódicos estiveram inseridos nos anos 1890 é perceber, como enfatiza Maria Helena Capelato, que a imprensa "é fruto de determinadas práticas sociais de uma época". ${ }^{4}$ Assim, os periódicos analisados, sobretudo a Revista Illustrada, não permaneceram com posiçóes imutáveis, mas, sim, adequaram seus conteúdos de acordo com o clima político do momento.

Os aniversários da abolição da escravatura nos anos 1890 e como eles foram noticiados nas páginas da Revista illustrada e do Don Quixote é um dos caminhos para averiguar esses posicionamentos e como ambos os periódicos se inseriram no debate político. Em outras palavras, o objetivo desse artigo pode assim ser definido: como um evento de extrema importância para a vida política, econômica e social e que foi promovido pelo Império do Brasil — a abolição da escravatura - foi abordado nas páginas dos periódicos durante a república? As respostas para esse questionamento serão buscadas na análise das ilustraçôes e artigos sobre as comemoraçóes do fim da escravidão.

\section{Revista Illustrada e Don Quixote: algumas consideraçóes sobre a república}

Para a Revista Illustrada, o crescimento da propaganda republicana somente aumentou "Por despeito, por ódio a abolição, acabam de rebentar diversos manifestos republicanos". 5 Este artigo era assinado por Julio Verim, pseudônimo de Luiz de Andrade, sócio de Agostini e que estava à frente do periódico naquele momento. Na continuação de seu texto afiançava que a campanha dos republicanos não surtiria os efeitos esperados já que a "monarquia se tornou popular e querida. Vocês estáo errados. Agora é um pouco tarde". O mesmo articulista ainda criticava a união dos antigos republicanos com aqueles que se tornaram simpatizantes da república após a aboliçáo: "Adeptos sinceros de uma ideia, se se unem, se se nivelam com os que a exploram, torpemente, não se queixem, se amanhã toda a gente os medir pela mesma craveira."'

A opinião da Revista se referia aos novos republicanos, que esperavam por uma indenização do governo pela liberdade concedida aos seus escravos. No entanto, vale assinalar que o fim da monarquia não foi ocasionado apenas por esse novo apoio. Conforme aponta Maria Viotti da Costa, essa ideia nasceu da "apreciação superficial e apressada dos fatos, é apenas em parte verdadeira". Ainda, segundo a autora, a abolição foi o golpe final "numa estrutura colonial de produção que a custo se mantinha perante as novas condiçóes surgidas no país, a partir de 1850".

Illustrada (1876/1898), sintese de uma época. Dissertação (Mestrado em História Social) — Programa de Pós-Graduação em História Social, Universidade Federal do Rio de Janeiro, Rio de Janeiro, 1988.

${ }^{4}$ CAPELATO, Maria H. Rolim. Imprensa e História do Brasil. São Paulo: Contexto, 1988, p. 24.

${ }^{5}$ Revista Illustrada, 16/06/1888, n. 501.

${ }^{6}$ Revista Illustrada, 23/06/1888, n. 502.

${ }^{7}$ COSTA, Emilia Viotti da. Da monarquia à república. Momentos decisivos. São Paulo: Editora da Unesp, 2007, p. 456-457. 
Entre outros motivos à proclamação estava a atuação da propaganda republicana iniciada em 1870 com a Fundaçáo do Partido Republicano no Rio de Janeiro. Contudo, apenas Quintino Bocaiúva participou do ato do dia 15 de novembro de 1889 e a atuação civil se tornou mais evidente nos anos posteriores. ${ }^{8} \mathrm{~A}$ propaganda republicana apareceu nas páginas da Revista e a sua opiniáo sobre os republicanos nem sempre foi como a abordada acima. Desde sua fundação em 1876 o periódico veiculava artigos e ilustraçóes em tom simpático para com os ideais republicanos. Um exemplo é o tom amistoso entre a redação do periódico e os republicanos Joaquim Saldanha Marinho e Quintino Bocaiúva.

Apesar das opiniōes sobre os republicanos veiculadas em 1888, a notícia da proclamação da república não foi uma surpresa para a Revista. $\mathrm{O}$ número de novembro, que seria lançado logo após o ato, estava com a edição fechada, mas um espaço para uma nota foi encontrado:

A hora de entrar a nossa folha no prelo os atos do gabinete 7 de junho e a indiferença da coroa a tantos abusos deram os seus legítimos frutos: foi proclamada a República Federal Brasileira, único regime que convém a nossa pátria e que havia de ser um fato mais hoje mais amanhã. O gabinete demissionário precipitou porém os acontecimentos, e hoje em plena paz, do meio do regozijo popular, saúda-se de todos os lados o novo e fecundo regime da democracia, do direito e do futuro da América.

Nestas mesmas colunas, há apenas dois meses, analisando os atos do ministério, dissemos que o Sr. Afonso Celso estava representando para a República o mesmo papel que o Sr. Barão de Cotegipe representara para a Abolição.

Realizaram-se os nossos vaticínios, e sentimo-nos felizes, por que isso tenha acontecido, em meio do regozijo e da confraternização mais admirável que se tem visto entre o Povo, Exército e a Armada nacional.

Honra ao civismo dos brasileiros. ${ }^{9}$

O periódico destacava que as razóes que levaram ao advento republicano foram os atos do Gabinete e a indiferença da Coroa. Ainda, a proclamação era esperada pela folha, que apontava o presidente do conselho como o principal responsável pela mudança, da mesma forma que o barão de Cotegipe foi importante para consolidar a abolição. A Revista opôs-se a ambos os ministros, embora o combate ao primeiro fosse mais intenso devido à causa abolicionista. A notícia, que foi sucinta e não assinada, enfatizava que a mudança política no país sucedeu em paz e foi recebida com alegria pela população, mesmo sentimento compartilhado pelo periódico. ${ }^{10}$

${ }^{8}$ CASTRO, Celso. Os militares e a república. Um estudo sobre cultura e ação política. Rio de Janeiro: Jorge Zahar Editor, 1995.

${ }^{9}$ Revista Illustrada, 16/11/1889, n. 569.

${ }^{10}$ Sobre a proclamação da república e a sua recepção pela população do Rio de Janeiro: CARVALHO, José Murilo. Os bestializados. O Rio de Janeiro e a república que não foi. São Paulo: Companhia das Letras, 1987. 
A recepção tépida à proclamação provavelmente ocorreu devido ao número já estar no prelo. No número seguinte, o primeiro do mês de dezembro, manifestaçôes enfatizando a chegada da república surgiriam nas páginas do periódico. A atitude se igualava àquelas tomadas por instituiçôes e antigas repartições ligadas ao império, assim como manifestaçôes pessoais de adesão a república. ${ }^{11}$

Julio Verim escreveu um artigo intitulado "Estados Unidos do Brasil" assinalando que o heroísmo da proclamaçáo da república se igualava à independência, à Lei de 28 de setembro de 1871 e à abolição da escravatura. A república era considerada por ele como o coroamento necessário a essas outras "conquistas do progresso", o que ocorreu no dia 15 de novembro "enchendo de desvanecimento os coraçôes brasileiros e assombrando o mundo". ${ }^{2}$

Nota-se que a recepção a proclamaçấo veiculada nas páginas da Revista Illustrada destoa do discurso contrário à república veiculado no pós abolição, conforme as citações anteriores evidenciaram. Já esse posicionamento simpático à república verificado no número de dezembro de 1889 perdurou ao longo dos anos de circulação do periódico até o seu encerramento em 1898. Isabel Lustosa destaca que com a república a Revista iniciou o "ciclo de heróis": "O enfermiço Marechal Deodoro da Fonseca, por exemplo, se verá, nas páginas da Revista Illustrada, glamourizado, rejuvenescido e cheio de vitalidade."13

A posição da Revista Illustrada náo foi ao longo dos primeiros anos apenas, e totalmente, contemplativa dos governos de Deodoro da Fonseca e Floriano Peixoto; em alguns momentos críticas surgiam ao governo, como em 1891, quando um artigo declarava: "Bem amarga tem sido a nossa desilusão nestes últimos meses; jamais supusemos que o governo democrático pudesse servir de capa a uns tantos decretos dignos da mais completa repulsa". "Já no período de Prudente de Morais o periódico adotou uma posiçâo simpática ao seu governo; o presidente "tem ido com muita moderação, estudando os fatos, resolvendo os problemas e mantendo-se num certo equilíbrio". ${ }^{15}$ Essa opiniáo se manteve no periódico por quase todo o período que acompanhou o governo de Prudente de Morais.

Durante o governo de Prudente de Morais Agostini retornou para o Brasil. A moderação e os estudos dos fatos, conforme apontava a Revista, não mereceram a mesma opiniáo do caricaturista, ao contrário, foi motivo de críticas. Em seu novo jornal, o Don Quixote, Agostini se referia ao presidente do Brasil apenas com um trocadilho: Prudente de Mais.

Vale destacar que o periódico foi lançado depois que Prudente de Morais assumiu a presidência, assim, a posição do jornal se desenvolveu concomitante ao seu governo e não em

\footnotetext{
${ }^{11}$ LEMOS, Renato. Benjamin Constant — vida e história. Rio de Janeiro: Topbooks, 1999, p. 413-422.

${ }^{12}$ Revista Illustrada, 07/12/1889, n. 570.

${ }^{13}$ LUSTOSA, Isabel. O texto e o traço: a imagem de nossos presidentes através do humor e da caricatura. In: FERREIRA, Jorge; DELGADO, Lucilia de Almeida (Orgs.). O Brasil republicano. O tempo do liberalismo excludente. Rio de Janeiro: Civilização Brasileira, v. 1, 2003, p. 294.

${ }^{14}$ Revista Illustrada, fevereiro/1891, n. 614.

${ }^{15}$ Revista Illustrada, janeiro/1895, n. 674.
} 
relação aos presidentes anteriores. Se os descontentamentos entre Agostini e os responsáveis pela Revista foram ocasionados pela bajulação publicada no período inicial da república, como foi apontado anteriormente, o momento do lançamento do Don Quixote parece sugerir que essa provável divergência de opiniôes motivou a criação do novo jornal e que elas foram mantidas, já que as referências ao governo de Prudente de Morais se afastavam daquelas veiculadas na Revista.

O novo título dado ao periódico por Agostini se referia a um personagem conhecido da literatura universal. Trata-se de uma referência ao livro Don Quijote de La Mancha, de Miguel de Cervantes. Don Quixote e seu fiel escudeiro Sancho Pancha, os protagonistas do romance, também foram aproveitados por Agostini, que os transformou nos personagens símbolos do periódico. Os dois apareciam no cabeçalho do jornal e quase sempre interagiam com os assuntos abordados nas ilustraçóes. O Don Quixote, contudo, era mais do que apenas um personagem, era o próprio Agostini que se colocava caricaturado. ${ }^{16}$ As opinióes emitidas nas ilustraçôes e nos artigos identificam o posicionamento do artista no que tange às questôes políticas, as quais divergiam daquelas veiculadas na Revista Illustrada. A análise que doravante será desenvolvida, a partir das consideraçóes de ambos os periódicos sobre os aniversários da abolição, evidenciará os posicionamentos e o lugar dos periódicos no debate político naquele momento.

\section{Os aniversários da abolição da escravatura nas páginas da Revista Illustrada e do Don Quixote}

A Revista Illustrada, como foi visto, se pautou pela defesa da causa abolicionista. Dessa forma, as comemoraçôes do 13 de maio não passariam despercebidas. ${ }^{17}$ Contudo, como abordar e celebrar o resultado positivo do fim da escravidão, realizado pelo império, no novo cenário republicano? A saída encontrada pela redação do periódico foi associar uma realização à outra, ou seja, o periódico relacionou a abolição da escravatura com a proclamação da república.

Essa relação se tornou evidente nas comemoraçôes do segundo aniversário da libertação dos escravos. Nas páginas centrais do número 590, de maio de 1890, o periódico apresentava aos seus leitores a festa promovida pela Confederação Abolicionista (Figura 1). Já o artigo de Julio Verim identificava a Confederação Abolicionista como a responsável pelo

\footnotetext{
${ }^{16}$ MOREIRA, Sandra. A presença do mito quixotesco no jornal ilustrado Don Quixote (1895-1903) de Angelo Agostini. Dissertaçáo (Mestrado em Língua Espanhola e Literaturas Espanhola e Hispano-Americana) Programa de Pós-Graduação em Língua Espanhola e literaturas Espanhola e Hispano-Americana. Universidade de São Paulo, São Paulo, 2001.

${ }^{17}$ A Revista comemorou o primeiro aniversário da abolição da escravatura em maio de 1889 , no entanto, optou-se por tratar somente dos aniversários nos anos 1890.
} 
processo que levou à liberdade dos escravos: "a associação que mais eficazmente lutou com o monstro, e que mais fundo o feriu com a lança da liberdade". ${ }^{18}$ A Confederaçáo Abolicionista ilustra o estandarte colocado atrás das duas alegorias e foi representada por um de seus membros, o cavalariano que acompanha o carro. Acima, num retrato integrado ao todo do desenho, estão os "iniciadores dos festejos”: João Clapp e José de Seixas Magalhães. ${ }^{19}$

Já na parte esquerda, a ilustração apresenta uma alegoria feminina que representava a Capital Federal. Ela levanta a cortina possibilitando aos leitores visualizarem a festa organizada para celebrar a data. Com a outra mão ela joga flores no caminho que logo será percorrido pelo cortejo que se aproxima. Essa alegoria possui na cabeça uma pequena estrela que poderia ser uma referência a um dos estados — provavelmente o Rio de Janeiro, a capital federal - que compóe a República Federativa do Brasil e estava, juntamente com as outras estrelas que representavam os demais estados, na esfera celeste da bandeira republicana. ${ }^{20}$

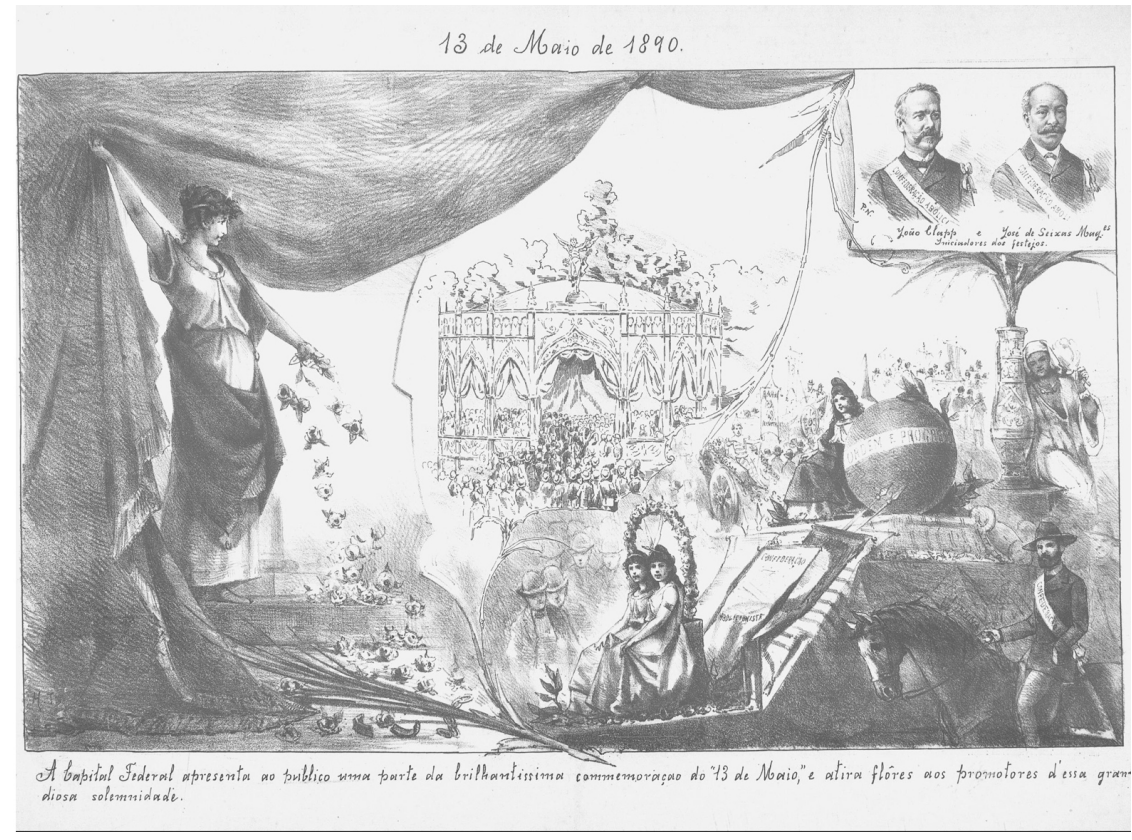

Figura 1 - Aniversário da abolição da escravatura comemorado em 1890 Fonte: Revista Illustrada, Rio de Janeiro, maio/1890, n. 590, p. 4 e 5. Acervo: Hemeroteca Digital da Biblioteca Nacional, Rio de Janeiro (http://bndigital.bn.br/hemeroteca-digital/)

\footnotetext{
${ }^{18}$ Revista Illustrada, maio/1890, n. 590.

${ }^{19}$ João Clapp foi companheiro de André Rebouças e José do Patrocínio, dois nomes importantes do movimento abolicionista do Rio de Janeiro e era conhecido, como aponta Daniel Aarão Reis, como um "abolicionista popular”. FILHO, Daniel Aarão Reis. Intelectuais, história e política. Séculos XIX e XX. Rio de Janeiro: Sette Letras, 2000, p. 65. Já José de Seixas Magalhães foi o idealizador do Quilombo do Leblon, uma chácara de sua propriedade que abrigava escravos fugidos que cultivavam camélias. SILVA, Eduardo. As camélias do Leblon e a abolição da escravatura. Uma investigação de história cultural. São Paulo: Companhia das Letras, 2003.

${ }^{20}$ Sobre a bandeira republicana ver: CARVALHO, José Murilo. A formação das almas. O imaginário da República no Brasil. São Paulo: Companhia das Letras, 1990, capítulo 5, p. 109-128.
} 
Na parte central, ao fundo, está localizado o espaço no qual o percurso do desfile acabava e a festa acontecia. É possível verificar um grande número de participantes que tomavam parte na Celebração. O negro, motivo principal da festa, não foi o que mais se destacou no desenho do caricaturista. Ele aparece, de forma mais visível, no lado direito, na parte traseira de um tipo de carro alegórico. Trata-se de uma mulher, usando túnica e turbante; em uma das mãos está um leque e seu corpo se apoia no vaso que faz parte dos elementos presentes no carro.

$\mathrm{Na}$ parte inferior da ilustração, no carro alegórico, surgem outras três alegorias femininas. As duas primeiras estão sentadas na parte frontal do carro como se fossem as suas condutoras. A outra está em destaque no alto. Esta é a alegoria que identifica a participação republicana no préstito. Algumas consideraçôes sobre esta parte da ilustração explicam, de forma mais evidente, a relação entre abolição e república pretendida pelo jornal.

As alegorias femininas são imagens que correspondem a ideias abstratas e foram difundidas, sobretudo, após o contexto revolucionário francês do final do século XVIII e no século XIX. Jean Starobinski ressalta que o emprego das alegorias já estava presente na arte antes dos eventos pós-1789: “(...) precede à revolução; o gosto neoclássico se afirmou e se difundiu em seguida, a partir de 1750 . As formas que a Revolução porá a seu serviço já estâo inventadas antes de 1789". ${ }^{21}$ Assim, elas podem representar uma cidade, semelhante a alegoria colocada na ilustração como a capital federal. Ainda, evidenciam ideais de liberdade, igualdade, fraternidade e república. Seu emprego se originou, contudo, a partir da alegoria da Liberdade: "A Liberdade, em certo sentido, é a essência da República, ela fornece seu emblema, e assim a consideraram; contudo ela não acabou e, de outra parte, de par com a Igualdade e a Fraternidade, é um elemento da tríade da virtude que forma a divisa republicana." 22 Em outras palavras, a alegoria da República é o resultado de uma adaptação da alegoria da Liberdade que, apesar de formar uma tríade com a Igualdade e a Fraternidade, se destacou entre as outras.

Retornando para a alegoria presente na ilustração é possível classificá-la a partir do que foi exposto acima. Ela é sim uma alegoria da Liberdade, conforme seu barrete frígio, que é um símbolo de identificação da liberdade. Ela, igualmente, também é uma significação da República do Brasil, uma vez que traz consigo a esfera celeste da bandeira republicana. Novamente é Maurice Agulhon, ao tratar das alegorias na França, quem esclarece a diferença. Para ele, a propagação das estátuas, cortejos e das festas proporcionou que a imagem alegórica da liberdade, associada ou confundida com a ideia de república, entrasse na memória visual dos

\footnotetext{
${ }^{21}$ STAROBINSKI, Jean. 1789. Os emblemas da razão. São Paulo: Companhia das Letras, 1988, p. 17.

${ }^{22}$ No original: "La Liberté, en certain sens, est l'essence de la République; elle lui a fourni son emblème, on l'a vu, mais elle ne cesse pás d'être, d'autre part, de pair avec l'Egalité et la Fraternité, un élement de la triade de vertus qui forme la divise républicaine”. AGULHON, Maurice. Marianne au combat. L'imagerie et la symbolique républicaines de 1789 à 1880. Paris: Flammarion, 1979, p. 30. (grifos no original) (tradução do autor)
} 
franceses. ${ }^{23}$ Tomadas as medidas proporçôes entre o caso francês e o brasileiro, ${ }^{24}$ essa também é a relação feita na ilustração da Revista Illustrada. Nota-se, por exemplo, que um dos braços da alegoria não aparece no desenho, o que indica que ela está segurando a esfera.

A sequência do artigo de Julio Verim corrobora a relação: "A cidade enfeitou-se, as autoridades concorreram às comemoraçôes, as músicas tocaram hinos festivos e o povo saiu para as ruas a dar vivas à liberdade, à abolição e à república." A república que o povo congraçava nas ruas era aquela da ideia abstrata concretizada em 1889, mas também era a imagem da república presente no carro alegórico do desfile comemorativo.

Já a colocação do globo da bandeira brasileira não remete apenas à questão republicana, que traria a ordem e o progresso para o Brasil, igualmente simbolizava a nova fase inaugurada há dois anos com o fim da escravidão. Assim, o progresso também poderia ser considerado como algo conquistado já em 1888 quando o país se libertou das amarras que o seguravam ao retrocesso - a escravidão - e possibilitou o passo seguinte: o surgimento da república. Ao festejar o seu passado abolicionista o periódico associava a ele um "passado" republicano do qual somente tomou parte no momento da proclamaçáo da república. A participação do periódico nesse processo é vista num dos carros, naquele que está colocado no segundo plano do desenho. Este é o carro da Revista Illustrada, que apresenta como figura principal o menino símbolo do periódico. Ele carrega um estandarte com a inscrição "Revista Illustrada", mostrando que também faz parte da celebração comemorada naquela data.

A associação entre a república e a abolição se tornou mais clara nas comemorações do terceiro aniversário da lei, em 1891 (Figura 2). A alegoria feminina da república surge com seu barrete frígio na cabeça e a bandeira da República do Brasil colocada num mastro e envolta em seu braço. Dessa forma, se por um lado a alegoria pode ser vista como apenas uma alegoria da liberdade, devido ao barrete frígio, por outro, identifica também que é uma alegoria da república brasileira, conforme as discussóes acima apontaram.

\footnotetext{
${ }^{23}$ Ibidem, p. 35-36.

${ }^{24}$ Para compreender as proporçôes entre o caso francês e o brasileiro é fundamental a relevante análise desenvolvida por José Murilo de Carvalho em sua obra A formação das almas no que se refere ao Brasil republicano. Para o autor o emprego e a difusáo de alegorias femininas enfrentaram várias adversidades: "Os obstáculos ao uso da alegoria feminina eram aparentemente intransponíveis. Ela falhava dos dois lados — do significado, no qual a República se mostrava longe dos sonhos de seus idealizadores, e do significante, no qual inexistia a mulher cívica, tanto na realidade como em sua representação artística. Nessas circunstâncias, a única maneira em que fazia sentido utilizar a alegoria era aproximar uma república considerada corrompida, ou pervertida, a prostituta”. CARVALHO, José Murilo. A formação das almas. O imaginário da República no Brasil, op. cit., p. 96. Já na França a alegoria da República foi empregada com afinco, especialmente com o surgimento da Terceira República (1870), com a proliferação de monumentos, estátuas, bustos, alto-relevos, fontes entre outros elementos decorativos e esculturas realistas. Maurice Agulhon considera essa proliferação de imagens como um fenômeno da história, relacionado com a história da decoração urbana e incluída por ele como parte da statuomanie francesa. AGULHON, Maurice. Historie vagabonde. Etnologie et politique dans la France conteporaine. Paris: Gallimard, 1988, p. 138-140.
} 
A ilustração foi concebida mais sóbria que a do ano anterior, sem detalhes dos festejos e dividindo a página com outros assuntos. Ela está num lugar que lembra uma fortaleza com uma estrutura com tijolos e o mar na sua frente, com o morro do Páo de Açúcar completando o cenário. Ao seu lado um canhão que, devido à fumaça que sai de sua boca, indica que foi há pouco deflagrado. No fundo da ilustração está uma nuvem de fumaça, resultado da detonaçáo recente do canhão. $\mathrm{O}$ alvo que ele atingiu foi a escravidáo e de seus destroços nasceu a abolição e a liberdade, conforme a inscrição "Lei 13 de maio" que sai do meio da fumaça proporcionando a "Data gloriosa", como apregoava o periódico na legenda. A alegoria colocada ao lado do canhão é vista como a responsável por sua detonação.

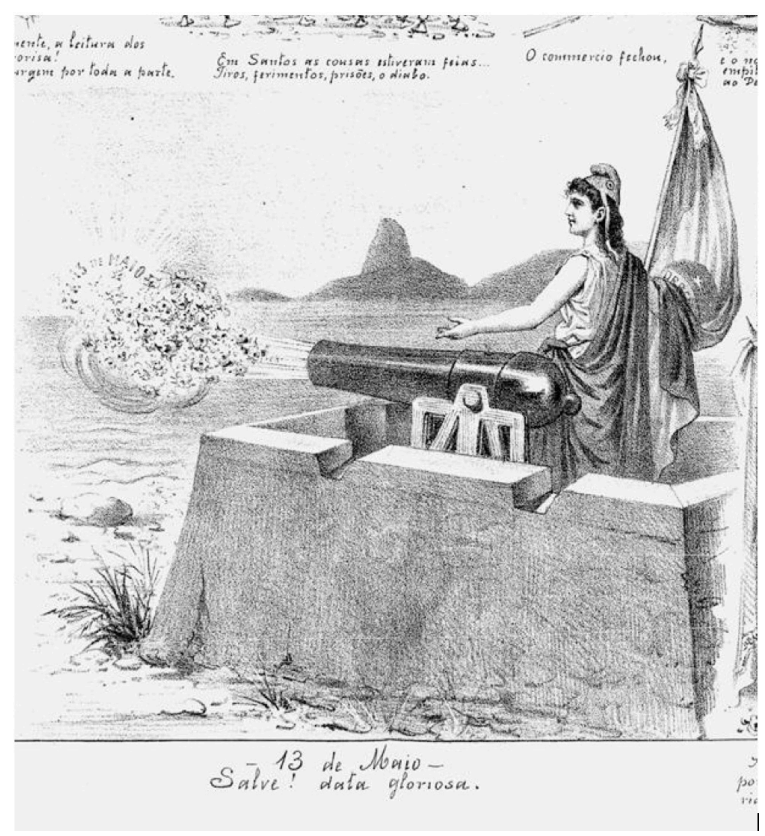

Figura 2 - Aniversário da abolição da escravatura comemorado em 1891 Fonte: Revista Illustrada, Rio de Janeiro, maio/1891, n. 621, p. 4 e 5. Acervo: Hemeroteca Digital da Biblioteca Nacional, Rio de Janeiro (http://bndigital.bn.br/hemeroteca-digital/)

A Revista, pelo que indica essa ilustração, transferia a realização abolicionista alcançada durante a monarquia para a república, esquecendo, por exemplo, da atuaçáo da princesa Isabel na sua concretização. Tanto nos textos veiculados durante as comemoraçóes do aniversário em 1890 como nos publicados neste ano, o nome da regente não foi mencionado; o foco foi dirigido para a Confederação Abolicionista e aos seus principais membros. $\mathrm{O}$ artigo de 1891 foi assinado por Farfarello, provavelmente um pseudônimo de Luiz de Andrade, e enaltecia a proposta de Rui Barbosa, colocada em prática, de destruir os documentos sobre a escravidão: "Reduziu-se à cinza os últimos vestígios da escravidáo no Brasil."25

${ }^{25}$ Revista Illustrada, maio de 1891, n. 621. 
Ainda neste texto, o articulista celebrava a data como sendo "o terceiro aniversário da nossa igualdade social”. A conclusão apontada pelo periódico se distanciava da condição do ex-escravo na realidade social brasileira. Olívia da Cunha e Flávio Gomes ressaltam que

A liberdade não foi restaurada; ao contrário, foi inventada e experimentada por aqueles que não a conheciam. Por isso, o território da liberdade é pantanoso e muitos dos sinais que sacralizaram a subordinação e a sujeição tornaram-se parte de um ambíguo terreno no qual ex-escravos e "livres de cor" tornaram-se cidadáos em estado contingente: quase cidadáos. O que fazer então com as marcas físicas e simbólicas desse passado, inalteráveis mesmo diante de operaçōes jurídicas, institucionais e simbólicas diversas? ${ }^{26}$

Ao contrário da colocação positiva da Revista Illustrada, a igualdade social não foi conquistada a partir do ato da abolição da escravatura em 1888 — ainda é um caminho tortuoso na história do Brasil. A conquista da cidadania foi algo lento e demorado e, por isso, os autores apontam que aqueles que foram alforriados se transformaram em "quase cidadãos". Contudo, a Revista parece desconhecer as desigualdades e celebra a data da abolição como sendo uma conquista de importantes abolicionistas, conforme a continuação do artigo: "Angelo Agostini, Seixas, Luiz de Andrade, André Rebouças, Dantas, Nabuco, João Ramos, Cordeiro, João Alfredo, e outros mais que não me ocorrem neste instante", ou seja, não há palavras a respeito das condiçóes dos ex-escravos no terceiro ano pós-lei, apenas para aqueles que lutaram em prol do fim da escravidão. Entre eles, Agostini e Andrade, proprietários da Revista.

A princesa Isabel, que surgiu em 1888 nas páginas da Revista Illustrada e de outros periódicos como a redentora responsável pelo fim da escravidão, agora, no cenário republicano, desaparecia. Ainda, o índio, outro símbolo constantemente usado pelos caricaturistas brasileiros no período monárquico, ${ }^{27}$ também deixou de figurar nos desenhos sobre a abolição. O seu desaparecimento se deu pois, apesar de representar o país, ele sinalizava aquele Brasil da monarquia. No cenário político republicano a Revista Illustrada passou a adotar apenas a alegoria. O clima político, portanto, também colabora com essa análise. O momento em que as duas ilustraçóes foram veiculadas era o mesmo da consolidação do

\footnotetext{
${ }^{26}$ CUNHA, Olívia Maria Gomes da; GOMES, Flávio dos Santos. Quase cidadão: histórias e antropologias da pós-emancipação no Brasil. Rio de Janeiro: FGV, 2007, p.13.

${ }^{27} \mathrm{O}$ índio como representação do Brasil surgiu na literatura. Como enfatiza Alfredo Bosi ele "nutriu largamente a fantasia de poetas, narradores e eruditos durante quase meio século". BOSI, Alfredo. História concisa da literatura brasileira. 43. ed. São Paulo: Cultrix, 1997, p. 100. Já em relaçáo ao seu emprego na imprensa ilustrada ele foi muito usado entre os caricaturistas no século XIX ao se referirem ao país ou ao império. Angelo Agostini já empregava essa analogia desde os seus tempos em São Paulo, assim como Henrique Fleiuss na fluminense Semana Illustrada. Ver: LIMA, Herman. História da caricatura no Brasil. Rio de Janeiro: José Olympio, 1963. TEIXEIRA, Luiz G. S. O traço como texto: a história da charge no Rio de Janeiro de 1860 a 1930. Rio de Janeiro: Fundação Casa de Rui Barbosa, 2001.
} 
novo regime, marcado, por exemplo, pelos adversários dos republicanos que defendiam o retorno da monarquia. ${ }^{28}$ Colocando as alegorias, o periódico, que no passado fora um fiel defensor da causa abolicionista e antipático aos republicanos após sua concretização, removia a impressão de ser um defensor do regime monárquico, substituindo o índio pela alegoria e evitando possíveis conflitos com o atual poder.

No ano seguinte a Revista saudou o aniversário do 13 de maio como "o dia glorioso da unificação da família brasileira" e ressaltou que a data representava um dos "fatos importantes" da história do país, que "preludiam grandes páginas históricas" ${ }^{29}$ Novamente o texto era assinado pelo pseudônimo Farfarello. Já as páginas destinadas às ilustraçôes abordaram outros assuntos. Na página oito, uma crítica leve ao governo de Floriano Peixoto comparando-o ao governo de Deodoro da Fonseca: Floriano se olha no espelho e o reflexo revela a imagem de Deodoro. Neste ano não surgiram alegorias, nem desenhos demonstrando as festividades. É possível que a justificativa para a ausência de desenhos sobre as comemoraçôes tenha ocorrido pelo fato de a Revista ter lançado apenas um exemplar no mês de maio desse ano. Assim, a redação e os artistas precisaram escolher quais notícias e ilustraçóes eram as mais relevantes naquele momento para publicar.

Em 1893 a associação república/abolição da escrvatura reapareceu na Revista com a publicaçâo de uma alegoria. Desta vez ela mereceu a primeira página e surgia elegante com os grilhôes da escravidão arrebentados em suas mãos (Figura 3). Abaixo, sob seus pés, está um globo com a inscrição "Brazil 13 de maio de 1888".

O periódico, ao colocar a alegoria como a responsável por arrebentar os grilhóes, transferia para ela a responsabilidade pela libertação dos escravos. $\mathrm{O}$ passado monárquico era apagado e substituído por um presente e uma mensagem para o futuro em que a abolição foi um benefício empreendido pela república. Outra leitura possível: a relação abolição/república pode ser vista nessa ilustraçáo como as duas benfeitorias realizadas em prol do progresso nacional. A abolição acabou com o último resquício de escravidão no continente americano e em seguida houve outra libertação, a política, que assegurou a totalidade de regimes republicanos nas Américas.

Todavia, a associação deixava de fora, de maneira mais evidente que nos anos anteriores, o passado monárquico e sua atuação na efetivação da liberdade dos escravos. Essa ilustração remete à princesa Isabel, uma vez que ela surgiu no pós-abolição segurando os grilhôes arrebentados e rodeada por escravos libertos, conforme exemplifica o desenho publicado pelo jornal La Avispa de Madri e reproduzido na Revista em 07 de julho de $1888 .{ }^{30}$ Contudo, o desenho de 1893 não deixa dúvidas de que se trata de uma alegoria republicana.

\footnotetext{
${ }^{28}$ Sobre os grupos que defendiam o retorno da monarquia: JANOTTI, Maria de Lourdes Mônaco. Os subversivos da República. São Paulo: Brasiliense, 1986.

${ }^{29}$ Revista Illustrada, maio/1892, n. 644.

${ }^{30}$ As imagens da princesa Isabel produzidas no pós-abolição podem ser consultadas em: JUNIOR, Robert Daibert. Isabel, a "Redentora" dos escravos. Bauru: EDUSC/FAPESP, 2004. A capa do jornal La Avispa foi reproduzida na página 145 do livro.
} 


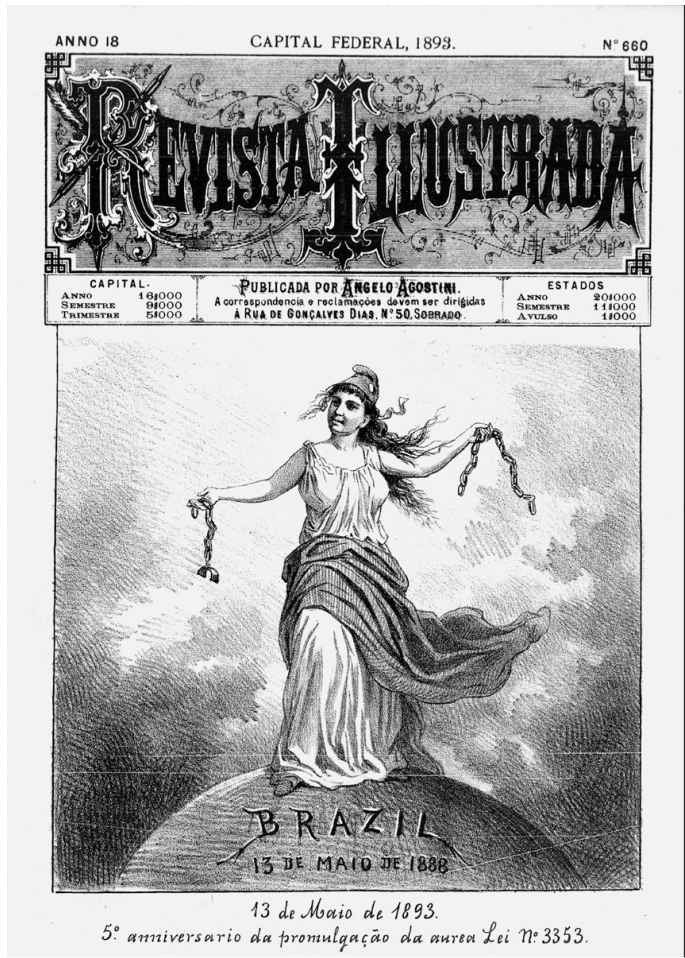

Figura 3 - Aniversário da abolição da escravatura comemorado em 1893 Fonte: Revista Illustrada, Rio de Janeiro, maio/1893, n. 660, p. 1. Acervo: Hemeroteca Digital da Biblioteca Nacional, Rio de Janeiro (http://bndigital.bn.br/hemeroteca-digital/)

Na nova situação política, que tentava apagar os resquícios do império, da qual surgia o ideal republicano, Isabel não tinha também mais lugar, nem mesmo nas ilustraçôes da Revista. Entretanto, duas reminiscências monárquicas permaneciam. Uma está na inscrição do globo, ou seja, a data da abolição, acompanhada do ano de sua promulgação; a segunda está na legenda que indica o número da lei, acompanhado do adjetivo "Áurea". O ano indicava ao leitor mais atento que a abolição foi realizada antes da proclamação da república e a adjetivação da lei remetia ao epíteto que ela recebeu logo após o documento ser assinado pela princesa.

Os aniversários posteriores da abolição não foram comentados pela Revista. Em 1894 a circulação ocorreu apenas entre os meses de novembro a dezembro. Em 1895 as duas ediçôes de maio não dedicaram nenhuma linha à data. O mesmo ocorreu em 1896. Nos anos de 1897 e 1898 o periódico novamente náo circulou no mês de maio. Parece que apesar de associar a abolição à república o periódico foi, nos anos posteriores aos primeiros aniversários, "apagando" definitivamente a história da escravidão no Brasil (associado também ao passado monárquico brasileiro), não restando espaço nem para as comemoraçóes.

Se a Revista Illustrada não veiculou nenhuma menção ao aniversário da abolição da escravatura em 1895, o Don Quixote, fundado neste ano, não esqueceu a data, a qual foi sempre 
comentada no mês de maio, sempre que o jornal foi publicado neste mês, durante os anos da sua circulação. Para começar a análise das páginas do Don Quixote sobre as comemoraçôes do 13 de Maio faz-se a mesma pergunta anterior, aplicada à Revista Illustrada: como abordar o resultado positivo do fim das escravidáo, realizado pelo império, no novo cenário republicano? Ao contrário da Revista, o Don Quixote abordou os aniversários associando a abolição com o império, sem, necessariamente, relacionar a república com a liberdade dos escravos.

O artigo publicado no dia 18 de maio de 1895, no 170 número, tratava das tentativas de alteração da participação dos abolicionistas e da Princesa Isabel nos resultados de 1888. Agostini criticava Barata Ribeiro, prefeito do Rio de Janeiro entre os anos de 1892 e 1893, pela colocação de uma placa numa das paredes do antigo Paço Imperial, localizado na praça Quinze de Novembro, na qual constava: "Por debaixo do nome do Marechal Floriano Peixoto em letras graúdas e do seu próprio nome em letras miúdas, está registrada a gloriosa data do decreto que extinguiu de um só golpe a escravidão do Brasil". ${ }^{31}$ Para o artista, tal atitude se tratava de uma tentativa de duvidar da "memória dos seus compatriotas". Conforme o artigo, somente agora aparecem os dois nomes na placa lembrando a "gloriosa data".

A crítica de Agostini demonstrava o seu descontentamento com a tentativa de burlar a história e apresentá-la de uma forma que não condizia com a veracidade da aboliçáo. Por um lado, seu texto desconstrói a associação entre república e abolição; por outro serve para criticar não só aqueles que tentavam relacionar uma data com a outra, como também tecia uma crítica ao governo Floriano Peixoto. Nas palavras de Agostini, a placa surtiu um efeito negativo, já que a colocação do nome do ex-presidente lembrou ao povo do "Estado de Sítio, dos fuzilamentos sem processos, dos cubículos da detenção". Para ele, a abolição da escravatura foi um acontecimento tão importante que não seriam necessárias placas para recordá-la. $\mathrm{O}$ povo lembraria da data, ela "não precisa de lápides despertadoras da memória, por que está gravada no coração, não só de todos os brasileiros, como de toda a humanidade, e passará às geraçôes futuras como a tradição mais santa e mais gloriosa de um povo".

O artigo escrito por Agostini, logo após se inserir novamente na imprensa ilustrada, demonstrava que sua antiga campanha em prol do fim da escravidáo realizada nas páginas da Revista Illustrada não foi esquecida. No novo periódico ele ressaltava que apesar de estar numa república, a abolição foi promovida pelo império, em especial pela princesa Isabel e pelos abolicionistas que, na sua opiniáo, mereciam ter seus nomes gravados na dita placa: "Se [na] Lápide tivessem gravados os nomes de José do Patrocínio, José Nabuco, Luiz Gama e outros que os secundaram, cercando o da entáo princesa Regente, o povo esqueceria tudo para se lembrar somente da Aboliçáo dos Escravos".

Marcelo Balaban escreve que depois da abolição Joaquim Nabuco organizou uma subscrição para presentear a Revista; a homenagem foi entregue durante um jantar no Hotel

${ }^{31}$ Don Quixote, 18/05/1985, n. 17. 
Globo oferecido à Antonio Bento, em agosto de $1888 .{ }^{32}$ Durante seu discurso, Joaquim Nabuco ressaltou a importância do papel desempenhado por Agostini que deu "corpo e vida” aos principais acontecimentos do país através de seu lápis. ${ }^{33}$ É possível considerar que o caricaturista, ao retornar para o Brasil, tenha percebido que sua Revista já não desempenhava mais esse papel e que o tom crítico já não dava mais "corpo e vida" aos acontecimentos republicanos ou, entấo, reescrevia a história, dando um novo sentido ao colocar a república como a responsável pela abolição.

Agostini, no seu novo periódico, igualmente escrevia a história da abolição, mas colocava os personagens correspondentes na sua realização, principalmente a atuação da princesa Isabel. Essa condição se tornou evidente na página oito do mesmo número 17. A regente então esquecida pela Revista retornava para demarcar o aniversário da abolição (Figura 4).

$\mathrm{Na}$ ilustração, intitulada: "O tempo passa, mas as datas gloriosas ficam", a figura do tempo, alado, surge segurando um livro. Em uma das páginas o número e a data da lei e parte de seu artigo primeiro: "É declarada extinta a escravidão no Brasil." Abaixo, a responsável pelo fim da escravidão: "Isabel Princesa Imperial regente". Na outra página do livro o desenho reproduz uma fotografia de Isabel. Uma escrava jogando flores no livro completa a comemoração da aboliçáo. O periódico também aproveitou a data para abordar a situação republicana.

Don Quixote aparece na ilustração saudando o livro erguendo seu chapéu em sua direção e com a outra mão segura sua espada, defendendo uma alegoria feminina da república de uma cobra. Ele ainda apoia o seu pé no dorso do animal enquanto Sancho Pança, ajoelhado, utiliza um porrete para bater nela. A alegoria olha para a cobra, com uma expressão de temor, se protegendo em seu manto enquanto sua inimiga direciona a ela suas presas.

A ilustração de Agostini permite algumas consideraçôes sobre a inserção do periódico no debate político daquele momento. Se, por um lado, o desenho trata da data do aniversário da abolição da escravatura, por outro, aborda a situação política da república, a qual Agostini se opunha. A legenda colabora com essa hipótese: "Salve! Augusta e benemérita Princesa! Liberaste uma raça, hoje trata-se de libertar a Pátria ameaçada por um terrível monstro que pretende devorá-la." A cobra, contudo, é ainda mais direta, ou seja, o monstro é a "política glicérica",

\footnotetext{
32 BALABAN, Marcelo. Poeta do lápis. Sátira e política na trajetória de Angelo Agostini no Brasil Imperial (1864-1888). São Paulo: Editora da Unicamp, 2009, p. 81.

${ }^{33}$ Quando Agostini faleceu, em 1910, O Paiz publicou que alguns dias antes de sua morte ele participou de uma reunião no edifício do Jornal do Commercio com antigos membros da Confederação Abolicionista para tratar das homenagens a Joaquim Nabuco, que recentemente havia falecido nos Estados Unidos. O texto, além de abordar uma das últimas atividades de Agostini, demonstra que a relação de amizade entre ambos ainda perdurava anos após o fim da escravidão e, igualmente, ressalta a sua participação nesse processo, já que a homenagem seria organizada por abolicionistas entre os quais se colocava. A citação de $O$ Paiz foi reproduzida em OLIVEIRA, Gilberto. Angelo Agostini ou impressóes de uma viagem da Corte à Capital Federal (1864-1910). Tese (Doutorado em História Social) — Programa de Pós-Graduação em História Social, Universidade de São Paulo, São Paulo, 2006, p. 315.
} 


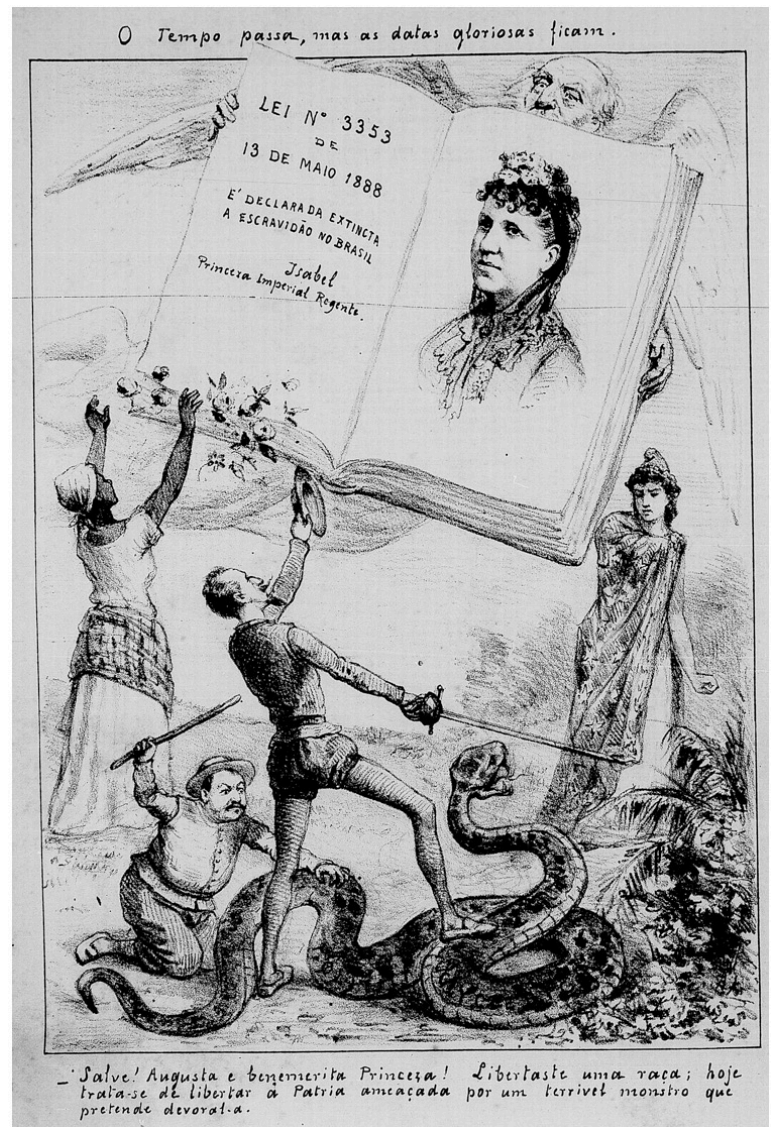

Figura 4 - Don Quixote e a Princesa Isabel no aniversário da abolição em 1895

Fonte: Don Quixote, Rio de Janeiro, 18/05/1895, n. 17, p. 8. Acervo: Hemeroteca Digital da Biblioteca Nacional, Rio de Janeiro (http://bndigital.bn.br/hemeroteca-digital/)

conforme a inscrição colocada ao longo de seu corpo. Trata-se de uma referência a Francisco Glicério, um político do começo da república que se tornou deputado federal e senador por São Paulo e que foi um dos principais apoiadores de Prudente de Morais até 1897.34

A explicação sobre esse posicionamento foi dada pelo próprio periódico no seu número 19. A ilustração foi explicada para esclarecer uma crítica publicada no jornal O Paiz. O artigo da folha ilustrada reproduzia um trecho do comentário do jornal republicano no qual constava que a ilustração era uma "invocação sebastianista" ${ }^{35}$ A defesa da ilustração assegurava que:

${ }^{34}$ SARMENTO, Silvia Noronha. A raposa e a águia: J. J. Seabra e Rui Barbosa na política baiana. Salvador: Scielo/EdUfba, 2011, p .50-51.

${ }^{35}$ Sebastianismo se refere ao rei português d. Sebastião (1554-1578), que desapareceu durante uma expedição contra os muçulmanos do norte da África. Como o corpo do rei nunca foi encontrado, acabou proporcionando o mito que ele retornaria para ocupar o seu lugar. GODOY, Marcio Honório de. Dom Sebastião no Brasil. São Paulo: Perspectiva, 2005. Assim, a "invocação sebastianista" significava que o periódico era favorável ao retorno da monarquia na visão de $O$ Paiz. 
Don Quixote saudou a princesa Isabel como signatária, que é, da Lei que libertou uma raça, e, seguindo o exemplo de outros órgáos da imprensa, que na comemoração do 13 de maio aludiram à nossa triste situação política, afirmou que se trata, agora, de libertar a pátria ameaçada - a república civil.

Eis o que O Paiz chama, faltando a verdade, uma invocação sebastianista. ${ }^{36}$

O periódico esclarece seu posicionamento: não é um periódico sebastianista e sim um defensor da república, mas contrário aos encaminhamentos dados pelos seus governantes. $O$ Paiz, que era o jornal da campanha republicana e que depois da proclamação da república defendeu o novo regime, ${ }^{37}$ fazia a defesa do governo, ou seja, de Prudente de Morais e de Francisco Glicério, e criticava a ilustração.

O periódico, ainda, aproveitava a polêmica criada pelo órgão republicano para reforçar o papel da princesa Isabel no processo da liberdade dos escravos. Na continuação do artigo assegura que a imprensa e as entidades que se bateram pela abolição não teriam conseguido conquistá-la sem a generosidade da princesa, a "ex-regente que, afinal, foi tão abolicionista como os que o mais eram, e assinou pressurosa e alegre a Lei 3353”. A continuação da longa resposta dada ao jornal republicano também enfocava a impossível dissolução entre Isabel e a promulgação da lei: "Ora, esquecer o nome dessa ilustre brasileira e não lhe dar o lugar a que tem incontestável direito na comemoração do 13 de maio, seria o mesmo que riscar do 15 de novembro o nome do Marechal Deodoro que, afinal de contas, foi o fundador da República”. Essa parte do texto colocava os nomes dos responsáveis pelas duas datas em seus devidos lugares, sem misturar a república com a abolição.

Esse entendimento do periódico era contrário àquele visto antes nas ilustraçóes da Revista Illustrada. O texto respondia às críticas feitas em $O$ Paiz, mas também parece se dirigir ao antigo jornal de Agostini, que comemorava a abolição a partir de um ponto de vista conciliatório com o regime republicano. $\mathrm{O}$ texto explicava ainda o posicionamento do jornal em relação a política republicana ora em curso; ressaltava que somente comemoraria a data da proclamação da república quando for "esterilizada para sempre a peçonha de uma política sanguinária e desastrosa”.

Agostini não era sebastianista, para ele a república estava consolidada, não havia sentido na volta do império. Por outro lado, isso não significava que a história da escravidão e a memória da abolição da escravatura fossem deturpadas. Para ele, a abolição foi promovida durante o império e pela monarquia, especificamente pela princesa Isabel. Dessa forma, a história deveria ser assim narrada, conforme ela ocorreu e não esquecendo completamente o seu passado. A frase que encima a ilustração ressalta esse posicionamento: "O tempo passa, mas as datas glo-

\footnotetext{
${ }^{36}$ Don Quixote, 01/06/1895, n. 19.

${ }^{37}$ Nelson Werneck Sodré destaca o "extremo servilhismo de O País" em relação ao seu posicionamento defensor dos primeiros governos do novo regime. SODRÉ, Nelson Werneck. História da imprensa no Brasil. São Paulo: Martins Fontes, 1983, p. 318.
} 
riosas ficam." Ele igualmente defendia a república, como o fez em muitos momentos, a forma de governo republicano, mas não concordava com aqueles que estavam no seu comando. Don Quixote, com sua espada, evitava que a república fosse atacada pelo monstro naquela ilustração.

O posicionamento republicano foi retomado na edição seguinte, no número 20 do periódico, em um artigo publicado na página 2. O texto tinha como objetivo discordar de uma proposta de criação na capital federal de um jornal monarquista. Contudo, o conteúdo publicado revelava mais do que uma mera crítica aos monarquistas; identificava a posição política do periódico e, portanto, de seu fundador, apesar do texto não ter assinatura, provavelmente foi escrito por Agostini. No começo destacava que a república tinha, desde a sua fundação, "atravessado crises notáveis, e sofre agora mesmo os efeitos dos erros cometidos principalmente em virtude da incapacidade ou má orientaçáo de muitos que a tem procurado servir". ${ }^{38}$ Essa afirmação não significava que o periódico fosse favorável ao retorno da monarquia e nem mesmo apoiasse a criação de um jornal de propaganda para este fim. A posição do periódico atestava que a república "fundada imprevistamente" é um "fato":

Não há dúvida alguma que a instituição republicana está definitivamente firmada e é a que nos pode dar a prosperidade material e a preponderância política de que todos somos dignos, como nação de riqueza e vastidáo excepcionais, neste belo continente americano.

Nutrindo esta convicção, reputamos positivamente má e infeliz toda ideia que visar a perturbação da vida da República, pela propaganda a favor de uma instituição, não mais possível de ser reimplantada, sem acarretar para a naçáo calamidades ainda maiores do que as que a República lhe tem imposto como pesado tributo. ${ }^{39}$

A defesa do ideário republicano fica clara e a crítica a monarquia também. Com este texto, Agostini esclarece e afasta qualquer dúvida sobre o seu posicionamento político: defensor da república, impossibilidade de retorno da monarquia e contrário a qualquer tipo de propaganda enaltecedora do antigo regime. $\mathrm{O}$ teor das frases igualmente remete a outra questâo importante neste momento da recente história da república: não há incertezas em relação ao regime republicano, a dúvida estava na ação dos seus condutores.

Essa posição de Agostini é semelhante àquela do grupo de intelectuais citados por Elias Saliba. Para o autor, a geração de Pardal Mallet, Lúcio de Mendonça, Paula Nei, Artur Azevedo, José do Patrocínio e outros constituíram um grupo que "cultiva o humorismo da 'desilusão' republicana até o momento em que o regime se torna mais estável, coincidindo com a emblemática reforma urbana do Rio de Janeiro" ${ }^{40}$ Em outras palavras, esses intelectuais, e

\footnotetext{
${ }^{38}$ Don Quixote, 08/06/1895, n. 20. Entre outros conflitos sociais que ocorriam naquele momento, Agostini se referia a Revolução Federalista de 1893 no Rio Grande do Sul.

${ }^{39}$ Don Quixote, 08/06/1895, n. 20.

${ }^{40}$ SALIBA, Elias Thomé. Raizes do riso. A representação humorística na história brasileira: da Belle Époque aos primeiros tempos do rádio. São Paulo: Companhia das Letras, 2002, p. 70.
} 
Agostini pode ser incluído entre eles, almejavam a república, mas se desiludiram com atitudes de quem estava no poder nos primeiros anos do novo regime. Saliba complementa: "O comportamento humorístico parecia corresponder a uma atitude geral do brasileiro no sentido de ajustar-se à vida na sua repetição cotidiana e àquela sobreposição de temporalidades, aparando ou, pelo menos, sublimando os impasses, os conflitos sociais e as perspectivas de futuro."\$1 Esse foi o tom do artigo de Agostini em relação a república; apesar dos problemas enfrentados naquele momento, o "pesado tributo", a perspectiva de futuro no cenário republicano será positiva e a forma de governo será incontestável.

Novamente a princesa Isabel é o destaque da página de Don Quixote que comemorou a abolição da escravatura no ano de 1896. Ela surge ocupando o centro da ilustraçáo desenhada em um busto (Figura 5). Bandeiras circulam a figura da princesa - uma delas apresenta um brasão do império e a outra é a bandeira republicana. Outra vez, o recurso do livro foi usado. Na parte superior a inscrição "História do Brasil" reforça a importância não apenas da abolição da escravatura, mas também de outra data: 1871 e a promulgação da Lei do Ventre Livre. Agostini, nesta ilustração, parece ainda mais audacioso do que naquela veiculada no ano anterior.

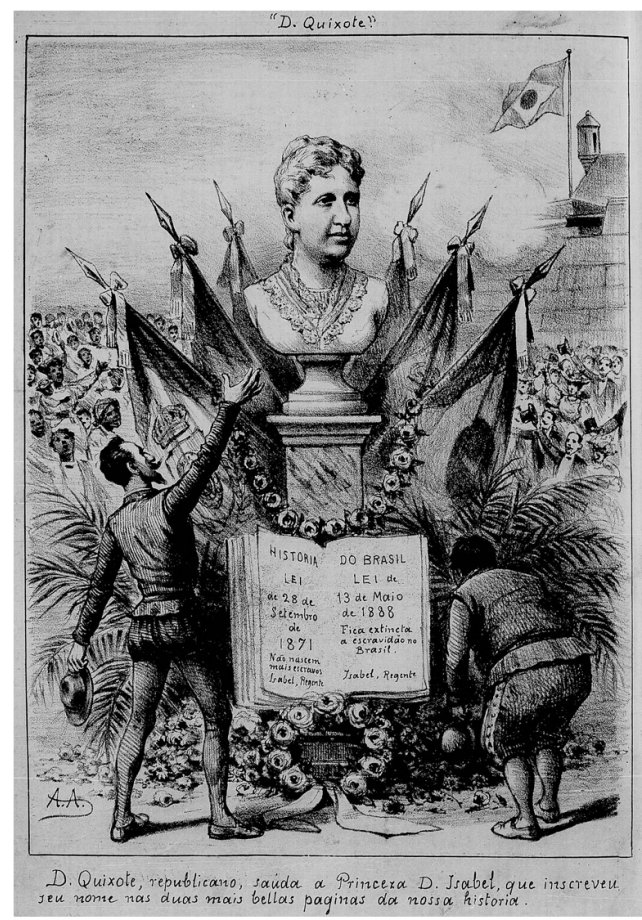

Figura 5 - Don Quixote e a Princesa Isabel no aniversário da abolição em 1896 Fonte: Don Quixote, Rio de Janeiro, 16/05/1896, n. 62, p. 8. Acervo: Hemeroteca Digital da Biblioteca Nacional, Rio de Janeiro (http://bndigital.bn.br/hemeroteca-digital/)

\footnotetext{
${ }^{41}$ Ibidem, p. 70.
} 
A referência ao império não ficou restrita apenas à imagem da princesa Isabel, ele relembrou outra lei direcionada aos escravos e mencionou um símbolo imperial. Don Quixote, o alter ego de Agostini, surge saudando a princesa acompanhado de Sancha Pança — é possível que a coroa de flores aos pés do busto tenha sido depositada por eles. Contudo, apesar da audácia, Agostini deixa evidente que ele e o seu periódico não são favoráveis ao retorno da monarquia. Essa afirmação está presente na legenda da ilustração: "Don Quixote, republicano, saúda a Princesa D. Isabel, que inscreveu seu nome nas duas mais belas páginas da nossa história." Vale lembrar que durante a promulgação de ambas as leis, Isabel ocupava o trono substituindo d. Pedro II que estava, nas duas ocasióes, fora do Brasil. ${ }^{42}$

A outra referência à república está no canto da ilustração, com a colocação de uma bandeira republicana hasteada, sinalizando que o Brasil, agora, é uma nação republicana. É possível que o canháo detonando uma bala — o que deixa uma parte do fundo da ilustração com uma nuvem de fumaça - também fosse uma referência à república. Canhóes pertencem ao Exército e, portanto, sua detonação representava uma forma oficial de o regime republicano celebrar a data.

Agostini optou por colocar pessoas comuns saudando a princesa em ambos os lados do busto. É possível que esse recurso tenha sido utilizado para deixar claro que não apenas o periódico referenciava a princesa como a responsável pelo fim da escravidáo, mas que o povo também assim a considerava.

Entretanto, apesar da forte relação que Agostini fazia entre a sua própria história como abolicionista e a comemoração da data, impressa nas páginas do seu periódico, ele colocou negros e brancos de lados opostos na ilustração. Analisando os rostos das pessoas que compóem o cenário do desenho é possível verificar que aqueles que estão do lado esquerdo são negros - destaque para a mulher que carrega uma criança e com o outro braço saúda a princesa enquanto outra criança segura a sua saia - e do outro lado são brancos. Nota-se que os homens deste lado usam suas cartolas para saudá-la e daquele os homens acenam com chapéus. A ilustração de Agostini demonstra a permanência do preconceito na sociedade brasileira, por outro lado, é importante destacar que a elaboração do desenho possivelmente remetia a uma constatação cotidiana e involuntária do artista e que não aponta, necessariamente, para uma visão preconceituosa do mesmo.

Em 1897 nenhuma ilustração foi publicada relativa à data da abolição da escravatura. Entretanto, no número 84, publicado no dia 15 de maio, um pequeno texto abordava o aniversário do fim da escravidão destacando as homenagens da imprensa fluminense a José do Patrocínio. No ano seguinte Don Quixote náo circulou e retornou somente em agosto de 1899. Novamente a circulação foi interrompida em 21 de abril de 1900, retornando às ruas somente

\footnotetext{
${ }^{42} \mathrm{O}$ imperador d. Pedro II realizou três viagens internacionais: entre 1871 e 1872 para a Europa e ao Oriente Médio, em 1876 para os Estados Unidos da América e em 1888 novamente para a Europa. SCHWARCZ, Lilia Moritz. As barbas do imperador. Dom Pedro II, um monarca nos trópicos. São Paulo: Companhia das Letras, 1998, p. 361, p. 373 e p. 431.
} 
em julho de 1901. A primeira interrupção foi ocasionada pela venda do prédio que sediava a redação do jornal, e a segunda, por uma enfermidade que impediu o caricaturista de manter a periodicidade, obrigando-o à não publicação por 13 meses. A data da abolição da escravatura retornou às páginas do periódico, pela última vez, no ano de 1902. Em fevereiro de 1903 houve uma nova interrupção, desta vez, definitiva. ${ }^{43}$

As ilustraçôes de 1902 comemoravam a data com destaque. Agostini elaborou a ilustração em três partes, ${ }^{44}$ espalhadas entre as páginas 4 e 5 do periódico (Figura 6). Para a divisão, utilizou um recurso gráfico diferente, ou seja, em vez de quadrinizar os temas, optou por dividi-los com um semicírculo, um arco envolvido por ramos e flores. No canto superior esquerdo, o desenho destacava a inauguração do monumento a José Maria da Silva Paranhos, o visconde de Rio Branco, localizado na Praça da Glória, no bairro de mesmo nome no Rio de Janeiro. ${ }^{45}$

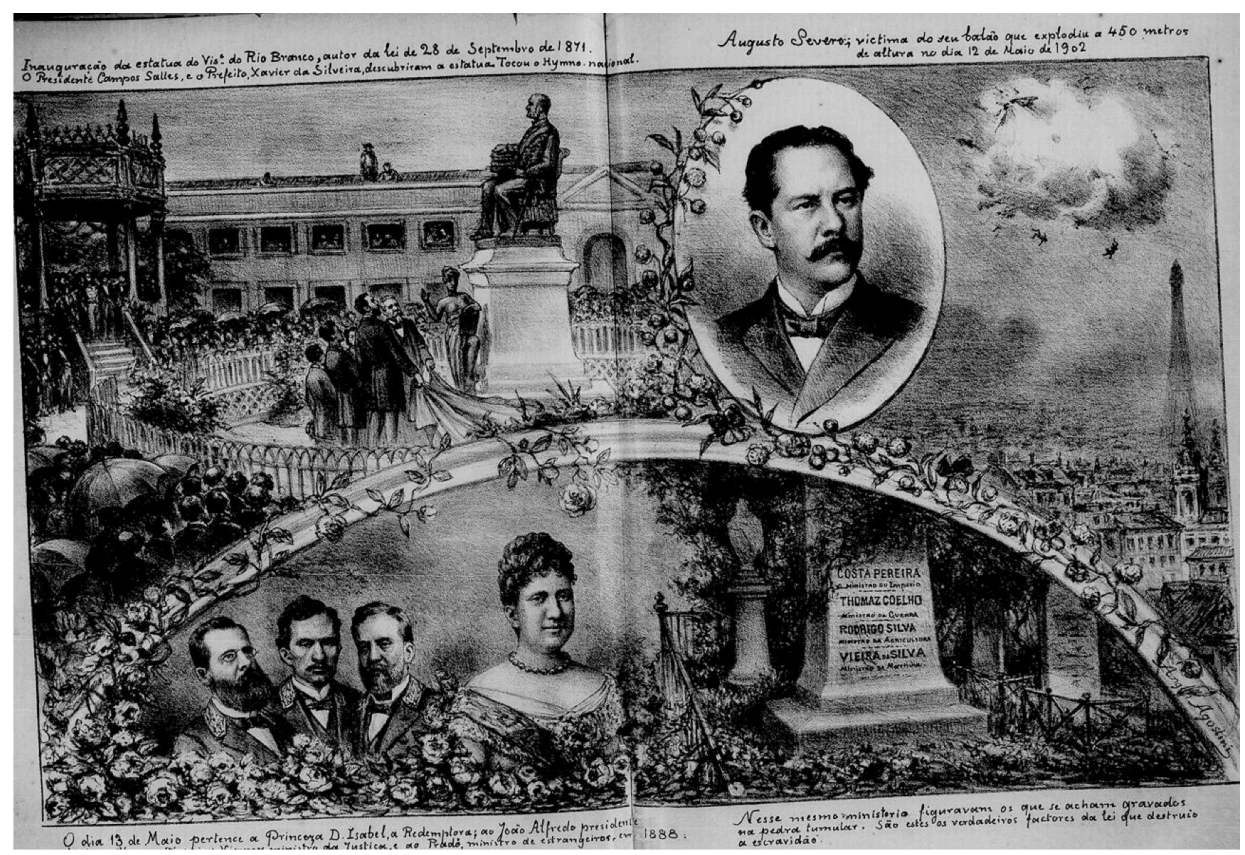

Figura 6 - Don Quixote e a Princesa Isabel no aniversário da abolição em 1902

Fonte: Don Quixote, Rio de Janeiro, 19/05/1902, n. 153, p. 4 e 5. Acervo: Hemeroteca Digital da Biblioteca Nacional, Rio de Janeiro (http://bndigital.bn.br/hemeroteca-digital/)

\footnotetext{
${ }^{43}$ Agostini passou a integrar a equipe de O Malho logo após o encerramento das atividades em Don Quixote. ${ }^{44}$ No canto superior direito, a ilustraçáo trata do acidente com o dirigível Pax, do brasileiro Augusto Severo de Albuquerque Maranhão (1864-1902), ocorrido em 1902 em Paris durante um voo experimental. Tal tema não será desenvolvido neste artigo.

${ }^{45}$ Atualmente o monumento está localizado na praça Demétrio Ribeiro, bairro de Copacabana, no Rio de Janeiro.
} 
A ideia da homenagem surgiu em 1881, por iniciativa do Jornal do Commercio, logo após o falecimento do visconde, no entanto, a inauguração ocorreu somente em 1902. A estátua do visconde o apresenta sentado vestindo o uniforme de senador do império. A fundição dos elementos que formam o monumento, feitos em bronze, foi realizada em Paris pelo escultor Charpentier. Na base do monumento está uma alegoria feminina, mas não se trata de uma referência à República; a figura da mulher representa a História. Ela está lendo a tábua que segura na qual está escrito, em latim, "Autoritate constantia fama ciarus", retiradas dos Anais de Tácito. ${ }^{46}$

O desenho do monumento revela que a inauguração foi acompanhada por autoridades, como o presidente da república, Campos Salles, o prefeito da capital federal, Xavier da Silveira, que descobriram a estátua do visconde. A solenidade atraiu um grande número de espectadores conforme sugere a imagem produzida por Agostini. Nela aparecem muitas pessoas ao redor do monumento, outras estão nas janelas e algumas no telhado do edifício ao fundo da ilustração. A notícia do evento, publicada no jornal Cidade do Rio, aponta que "Terminada a cerimônia de descerramento da estátua, a multidáo apinhada na praça, que era de cerca de cinco mil pessoas, rompeu em aplausos calorosos e prolongados". ${ }^{77}$

Novamente trata-se de uma celebração republicana que remete a um ato da monarquia. Como já foi visto, a princesa Isabel foi também a responsável pela assinatura da lei que promulgava a liberdade dos nascidos de mulheres escravas a partir de 1871 . No entanto, não há referências a ela no monumento, apesar da data da sua inauguração ser no aniversário da abolição. As festividades pelo fim da escravidão, promovidas pelo regime republicano, ocorriam; entretanto, nas formas da sua realização parece que tiveram o cuidado de não associar o império e os seus representantes diretos, como a princesa Isabel. Nestas circunstâncias, aproveitaram o aniversário da aboliçáo, em 1902, para inaugurar o monumento, que também remetia a uma figura de expressão do Brasil monárquico, mas que não era um membro da família imperial e sim um brasileiro que "dignificou a Pátria. Honrou a Humanidade". ${ }^{8}$ A ilustração não criticava o monumento ao visconde de Rio Branco e muito menos desconsiderava a sua atuação. Pelo contrário, Agostini reconhecia a relevância da justa homenagem, entretanto, o dia 13 de maio náo pertencia a ele e sim à princesa Isabel.

É possível que esta associaçáo entre a data da celebração da abolição e a inauguraçáo do monumento ao visconde seja a explicação para a continuação dos desenhos da parte inferior da ilustração. Agostini destacou mais uma vez a figura da princesa Isabel. Agora acompa-

46 Todas as informaçóes sobre o monumento foram consultadas em: Diário de Notícias. Monumentos da Cidade. Rio de Janeiro, 24/10/1943, n. 133, p. 8. Disponível em Hemeroteca Digital da Biblioteca Nacional, Rio de Janeiro (http://bndigital.bn.br/hemeroteca-digital/)

${ }^{47}$ Cidade do Rio, 14/05/1902, n. 189.

${ }^{48}$ Conforme o jornal Cidade do Rio (14/05/1902, n. 189) foi construído um pavilhão na praça para receber as autoridades. Na parte externa foram colocados painéis com inscriçóes que exaltavam a figura do visconde. Em um deles constam essas duas frases. A ilustração de Agostini não mostra o painel e o que aparece é o coreto construído para as apresentaçóes da banda de músicos do Corpo de bombeiros. 
nhada do gabinete que governou com ela em 1888: "O dia 13 de maio pertence a Princesa D. Isabel, a redentora; ao João Alfredo presidente do Conselho, ao Ferreira Viana, ministro da Justiça e ao Prado, ministro de Estrangeiros em 1888". Colocou também os demais ministros já falecidos: "Nesse mesmo ministério figuravam os que se acham gravados na pedra tumular. São estes os verdadeiros factores (sic) da lei que destruiu a escravidão". Agostini aponta no desenho os nomes de Costa Pereira, ministro do Império, Thomaz Coelho, ministro da Guerra, e Vieira da Silva, ministro da Marinha.

Duas palavras usadas nas legendas — pertence e verdadeiros — denotam a possibilidade de Agostini apresentar aos seus leitores os responsáveis pela lei que concedeu liberdade aos escravos. Ele é enfático: o ato celebrado no dia 13 de maio pertence à princesa Isabel e aos demais que com ela governavam o Brasil naquele momento, ou seja, esse grupo constituiu os verdadeiros nomes que deveriam ser celebrados nos aniversários da abolição. Enquanto isso, o visconde de Rio Branco foi o autor da Lei de 28 de setembro de 1871, conforme informa o próprio artista na legenda que encima o desenho.

\section{Considerações finais}

A análise das ilustraçóes e dos textos publicados nas páginas da Revista Illustrada e do Don Quixote demonstram que os aniversários da abolição da escravatura foram celebrados por ambos periódicos. As comemoraçóes, contudo, foram tratadas de forma diferente. $\mathrm{Na}$ produção da Revista Illustrada as comemoraçôes da abolição da escravatura foram transferidas, quase sempre, à república, que associava a abolição com as alegorias femininas da república, embora lembranças do período monárquico permanecessem em detalhes das imagens. Já na produção do Don Quixote, Agostini evidenciava a abolição como um feito do regime monárquico, destacava a participação da princesa Isabel e utilizava a sua imagem na confecção das ilustrações.

As escolhas de Agostini foram criticadas, contudo ele ressaltou em sua defesa que era impossível dissociar a promulgação da lei da princesa Isabel. As explicaçôes acabaram também revelando as consideraçôes do artista em relação a política republicana e qual o seu posicionamento no debate político dos anos 1890 .

Ambos os periódicos são considerados republicanos; porém a forma como se dedicaram ao ideário da república divergia. A Revista pode ser apontada como um jornal defensor da república, sem críticas à conduçáo da política naqueles anos ou, em determinados momentos, com um tom mais crítico, mas nunca exacerbado. O Don Quixote agia ao inverso: criticava aguerridamente os políticos republicanos em desenhos satíricos e textos de protesto, contudo não colocava o fim da república e o retorno da monarquia como a solução dos problemas, ao contrário: acreditava no futuro da república. Se, por um lado, a Revista Illustrada, des- 
tacava a abolição sem se referir à monarquia - afinal como fazer tal associação em uma nova realidade, republicana, e com uma censura severa $?^{49}$ - por outro, Don Quixote não se preocupava com possíveis reveses que a sua escolha poderia acarretar e empregava o passado monárquico para celebrar o 13 de maio.

A Revista Illustrada e o Don Quixote são dois importantes representantes da imprensa ilustrada brasileira. As formas diferentes como os aniversários da aboliçáo da escravatura foram tratados em suas páginas tornam os dois periódicos importantes fontes para compreender, entre outras questóes, o momento político da recém-inaugurada república no Brasil.

\section{Fontes e referências bibliográficas}

\section{Fontes}

Revista Illustrada, Rio de Janeiro, 1888-1898.

Don Quixote, Rio de Janeiro, 1895-1903.

Cidade do Rio, Rio de Janeiro, 1902.

Diário de Notícias, Rio de Janeiro, 1943.

Todos os jornais foram consultados na Hemeroteca Digital da Biblioteca Nacional, Rio de Janeiro, disponível em: <http://bndigital.bn.br/hemeroteca-digital/>

\section{Referência bibliográficas}

AGULHON, Maurice. Historie vagabonde. Etnologie et politique dans la France conteporaine. Paris: Gallimard, 1988.

. Marianne au combat. L'imagerie et la symbolique républicaines de 1789 à 1880. Paris: Flammarion, 1979.

\footnotetext{
${ }^{49}$ A censura à imprensa foi imposta logo após a proclamação da república. O presidente Deodoro da Fonseca se desentendeu com o jornal Cidade do Rio, que tinha como símbolo uma mulher nua e que constantemente aparecia junto com ele. LUSTOSA, Isabel. Histórias de presidentes. A república no Catete. Petrópolis/Rio de Janeiro: Vozes/Fundação Casa de Rui Barbosa 1989, p. 150. Em seguida houve o empastelamento do jornal $A$ Tribuna, dirigida por Carlos de Laet e de cunho monárquico e oposicionista. A imprensa do Rio de Janeiro se manifestou contrária ao atentado e organizou um protesto que reuniu todos os jornais da cidade independente das bandeiras políticas defendidas, entre os órgãos que assinaram o manifesto estava a Revista Illustrada. SODRÉ, Nelson Werneck. História da imprensa no Brasil. São Paulo: Martins Fontes, 1983, p. 290-291. Ainda: JUNIOR, Raimundo Magalhães. Deodoro, a espada contra o império. São Paulo: Companhia Editora Nacional, 1957, v. 2. Ver o capítulo: $\mathrm{O}$ assalto à redação de "A Tribuna", p. 238-257.
} 
BALABAN, Marcelo. A flor da nossa gente: análise de imagens de negros da Revista Illustrada. In: V Encontro Escravidão e Liberdade no Brasil Meridional. 2005, Porto Alegre. Anais... Porto Alegre: UFRGS, p. 01-24 (Anais eletrônicos).

. Poeta do Lápis. Sátira e política na trajetória de Angelo Agostini no Brasil Imperial (1864-1888). São Paulo: Editora da Unicamp, 2009.

BOSI, Alfredo. História concisa da literatura brasileira. 43. ed. São Paulo: Cultrix, 1997. CAPELATO, Maria H. Rolim. Imprensa e História do Brasil. São Paulo: Contexto, 1988. CARVALHO, José Murilo. A formação das almas. O imaginário da república no Brasil. São Paulo: Companhia das Letras, 1990.

. Os bestializados. O Rio de Janeiro e a república que não foi. Sáo Paulo: Companhia das Letras, 1987.

CASTRO, Celso. Os militares e a república. Um estudo sobre cultura e ação política. Rio de Janeiro: Jorge Zahar Editor, 1995.

COSTA, Emilia Viotti da. Da monarquia à república. Momentos decisivos. São Paulo: Editora da Unesp, 2007.

CUNHA, Olívia Maria Gomes da; GOMES, Flávio dos Santos. Quase cidadão: histórias e antropologias da pós-emancipação no Brasil. Rio de Janeiro: FGV, 2007.

FILHO, Daniel Aarão Reis. Intelectuais, história e política. Séculos XIX e XX. Rio de Janeiro: Sette Letras, 2000.

GODOY, Marcio Honório de. Dom Sebastião no Brasil. São Paulo: Perspectiva, 2005. JANOTTI, Maria de Lourdes Mônaco. Os subversivos da república. São Paulo: Brasiliense, 1986. JUNIOR, Raimundo Magalhães. Deodoro, a espada contra o império. São Paulo: Companhia Editora Nacional, 1957.

JUNIOR, Robert Daibert. Isabel, a "Redentora" dos escravos. Bauru: EDUSC/FAPESP, 2004. LEMOS, Renato. Benjamin Constant — vida e história. Rio de Janeiro: Topbooks, 1999.

LIMA, Herman. História da caricatura no Brasil. Rio de Janeiro: José Olympio, 1963.

LUSTOSA, Isabel. Histórias de presidentes. A república no Catete. Petrópolis/Rio de Janeiro: Vozes/Fundação Casa de Rui Barbosa 1989.

. O texto e o traço: a imagem de nossos presidentes através do humor e da caricatura. In: FERREIRA, Jorge; DELGADO, Lucilia de Almeida (Orgs.). O Brasil republicano. O tempo do liberalismo excludente. Rio de Janeiro: Civilização Brasileira, v. 1, 2003, p. 287-312. MOREIRA, Sandra Regina. A presença do mito quixotesco no jornal ilustrado Don Quixote (1895-1903) de Angelo Agostini. Dissertação (Mestrado em Língua Espanhola e literaturas Espanhola e Hispano-Americana) - Programa de Pós-Graduação em Língua Espanhola e Literaturas Espanhola e Hispano-Americana. Universidade de São Paulo, São Paulo, 2001. 
OLIVEIRA, Gilberto. Angelo Agostini ou impressôes de uma viagem da Corte à Capital Federal (1864-1910). Tese (Doutorado em História Social) — Programa de Pós-Graduação em História Social, Universidade de São Paulo, São Paulo, 2006, p. 197.

RIBEIRO, Marcus Tadeu Daniel. Revista Ilustrada (1876/1898), sintese de uma época. Dissertação (Mestrado em História Social) — Programa de Pós-Graduação em História Social, Universidade Federal do Rio de Janeiro, Rio de Janeiro, 1988.

SALIBA, Elias Thomé. Raizes do riso. A representação humorística na história brasileira: da Belle Époque aos primeiros tempos do rádio. São Paulo: Companhia das Letras, 2002.

SARMENTO, Silvia Noronha. A raposa e a águia: J. J. Seabra e Rui Barbosa na política baiana. Salvador: Scielo/EdUfba, 2011.

SCHWARCZ, Lilia Moritz. As barbas do imperador. Dom Pedro II, um monarca nos trópicos. São Paulo: Companhia das Letras, 1998.

SILVA, Eduardo. As camélias do Leblon e a abolição da escravatura. Uma investigação de história cultural. São Paulo: Companhia das Letras, 2003.

SODRÉ, Nelson Werneck. História da imprensa no Brasil. São Paulo: Martins Fontes, 1983.

STAROBINSKI, Jean. 1789. Os emblemas da razão. São Paulo: Companhia das Letras, 1988.

TEIXEIRA, Luiz G. S. O traço como texto: a história da charge no Rio de Janeiro de 1860 a 1930. Rio de Janeiro: Fundaçáo Casa de Rui Barbosa, 2001. 